\title{
CAcuayteratiorio
}

\section{Proyecto Memola}

\section{Paisajes mediterráneos de montaña: una aproximación histórica al patrimonio cultural basada en los agrosistemas tradicionales}

\author{
Mediterranean mountainous landscapes: an historical approach to cultural heritage \\ based on traditional agrosystems
}

\author{
http://www. memolaproject.eu
}

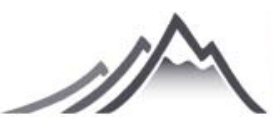

MEDITERRANEAN

MOUNTAINOUS

LANDSCAPES

El proyecto MEMOLA, acrónimo derivado del título en inglés: MEditerranean MOntainous LAndscapes, propone una aproximación interdisciplinar a los paisajes culturales montañosos del Mediterráneo, teniendo como eje central el estudio histórico de dos recursos naturales esenciales para la generación de los agrosistemas: el agua y el suelo.

El estudio se enfoca en cuatro áreas: Sierra Nevada (España), Monti di Trapani (Italia), Colli Euganei (Italia) y el Valle de Vjosa (Albania).

El concepto de paisaje cultural del que se parte atiende a cómo las lógicas que lo gobiernan y su estructura se encuentran fuertemente condicionadas por la necesidad de asegurar la supervivencia de las comunidades rurales. La construcción del paisaje está basada en estrategias de producción/ reproducción de las sociedades, cada una con sus propias características, que varían dependiendo del momento histórico. Por esta razón, la propuesta del proyecto es atender al paisaje a partir de aquellos procesos históricos que han intervenido en una relación específica con el medioambiente, orientada a la extracción y usos de los recursos en un determinado contexto social. Estos usos han ido moldeando profundamente el contexto medioambiental, generando no solo su forma, sino también las fórmulas culturales que han hecho posible su gestión y mantenimiento hasta el día de hoy. El concepto de paisaje se complejiza y aparecen tres niveles de análisis, atravesados por la perspectiva histórica; 1) El espacio natural, con su geología, biología y clima; 2) El espacio construido, con sus asentamientos, redes de comunicación y áreas de trabaj 0; 3) El espacio simbólico, con sus significados religioso, político y administrativo. Los paisa-
The MEMOLA project proposes an interdisciplinary approach to cultural landscapes of Mediterranean mountainous areas, taking as a central axis the historical study of two natural resources essential to generate agro-systems: water and soil.

The study focuses on four areas: Sierra Nevada (Spain), Monti di Trapani (Italy), Colli Euganei (Italy) and Vjosa Valley (Albania).

The concept of cultural landscape used assumes that the logics governing landscapes and their structure are strongly conditioned by the need of ensuring the livelihood of rural communities over time. The construction of landscapes is based on strategies of production and reproduction of societies, each one with their own different characteristics, throughout history. Therefore, to understand the landscape it is necessary to investigate the historical processes that have led to a specific relationship with the environment, aimed at the extraction and use of resources in certain social contexts. These uses have deeply molded the environmental context, generating not only its forms, but also the cultures that made possible its management and maintenance until today. The concept of landscape is divided in three different levels 1 ) the natural space, with its geology, biology, and climate; 2) the built space with its working areas, urban settlements and communication networks; 3) the symbolic space with its political, administrative and religious forms of perception. Landscapes need to be attended as constructs molded by successive generations of human experimentation and transformation, as well as by the interaction with material elements and natural processes. Thus, the MEMOLA 


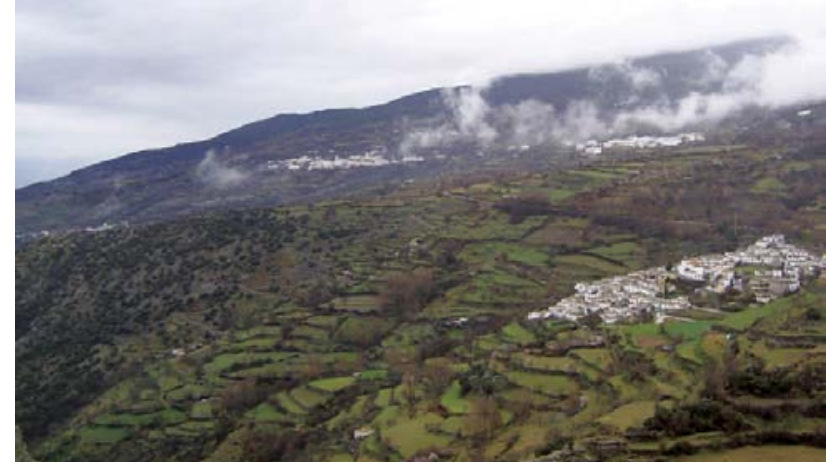

Sierra Nevada.

jes han de ser atendidos como constructos moldeados por sucesivas generaciones de experimentación y transformación humana, así como por la interacción con elementos materiales y procesos naturales. Así, el proyecto MEMOLA propone desarrollar un estudio diacrónico que permita atender a la relación entre las poblaciones rurales y los recursos naturales, especialmente agua y suelo, esenciales para la generación de los sistemas agrarios y los paisajes culturales en donde se encuentran insertos.

El conocimiento de las diferentes formas tradicionales en que los recursos naturales son explotados y gestionados a lo largo del tiempo, es crucial para la conservación del paisaje, así como para su adaptación a cambios globales actuales como la industrialización, el cambio climático, la pérdida del conocimiento campesino o la sobreexplotación de recursos naturales. En este sentido, las zonas montañosas en estudio representan casos importantes para el análisis de un patrimonio cultural tangible e intangible, actualmente expuesto a importantes cambios que pueden llevar a su desaparición. La recolección, registro y difusión de este complejo ensamblaje cultural representa un importante enriquecimiento en términos de cohesión social, identificación cultural y sensibilización social.

En el reconocimiento de la necesidad de incorporar una visión interdisciplinar en el estudio del paisaje cultural, el proyecto MEMOLA - cuya coordinación recae en la Universidad de Granada - se encuentra integrado por un equipo internacional de investigadores y expertos procedentes tanto del contexto académico como empresarial. Se trata en total de diez socios de cinco países diferentes (España, Italia, Albania, Inglaterra e Irlanda). Se integran tanto historiadores y arqueólogos, como antropólogos, agrónomos, botánicos, edafólogos, hidrólogos y arquitectos. Las instituciones públicas participantes son las universidades de Padua, Palermo, Córdoba y Sheffield, así como el CSIC-Escuela Española en Roma. Por su parte, las privadas son las empresas Eachtra Archaeological Projects y Arqueoandalusí, Arqueología y Patrimonio S. L. y las asociaciones Center of Research and Promotion of Historical and Archaeological Albanian Landscapes (CerPHAAL) y el Centro UNESCO Andalucía. Se trata, por lo tanto, de una aproximación integral al estudio del papel que los paisajes desempeñan en el patrimonio cultural europeo, con el objetivo de contribuir a su promoción y conservación.

Uno de los objetivos principales del proyecto corresponde a la labor de investigar, aplicando un análisis diacrónico, las lógicas project proposes to develop a diachronic study in order to attend the relationship between rural communities and natural resources, specially water and soil, essential for the generation of agricultural systems and the cultural landscapes in which they are inserted.

The knowledge of the different ways natural resources are exploited and managed over time, is crucial for landscape conservation and its adaptation to current global changes: globalization, agrarian industrialization, climate change, loss of peasant knowledge and rural population. In this sense, mountainous areas act as repositories for both tangible and intangible cultural heritage, whose socio-economic tissues are constantly submitted to erosion. The recollection, registration and diffusion of this complex heritage assemblage represent an important enrichment in terms of local social cohesion, cultural identification and social awareness.

Recognizing the importance of incorporating an interdisciplinary approach in the study of cultural landscape, the MEMOLA project, coordinated by the University of Granada (Spain), is integrated by an international team of researchers and experts coming from the academic and business context. A total of ten partners from five different countries (Spain, Italy, Albania, England and Ireland). It integrates historians and archaeologists, as well as anthropologists, agronomists, botanists, edaphologists, hydrologists and architects. The participant public institutions are the universities of Padova, Palermo, Córdoba and Sheffield, as well as CSIC-Escuela Española en Roma. Also, the private institutions participating in the project are Eachtra Archaeological Projects y Arqueoandalusí, Arqueología y Patrimonio S. L.; as well as the Center of Research and Promotion of Historical and Archaeological Albanian Landscapes (CerPHAAL) and the Centro UNESCO Andalucía.

One of the main objectives in the project is to investigate the logic that rules the process of historical landscapes formation in relation to natural resources within a diachronic framework. Conduct specific historical and archaeological study in the four study areas Quantitatively assess the long-term historical uses of water and soils in each territory. Analyze the agrosystems (crops and livestock), and the productivity and resource efficiency in the four historic-sample-areas.

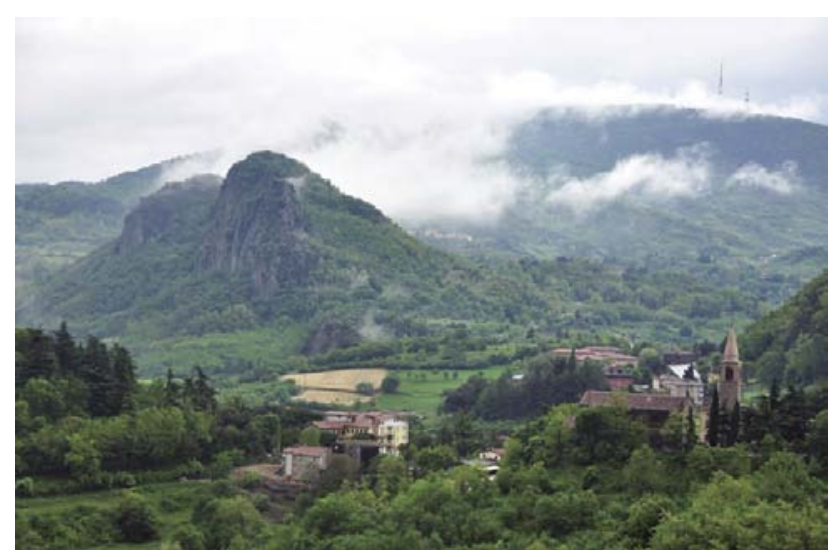

Colli Euganei. 


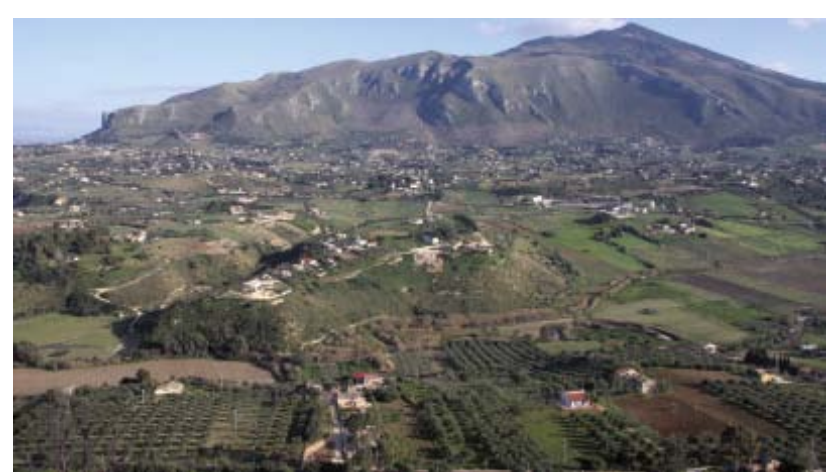

Monti di Trapani.

que gobiernan los procesos históricos de formación del paisaje en relación a los recursos naturales. Para ello se están desarrollando estudios histórico-arqueológicos en las cuatro áreas de estudio descritas a fin de evaluar en cada territorio el uso histórico por las poblaciones del agua y los suelos. Así mismo se están llevando a cabo análisis de los agrosistemas (cultivos y ganadería), y de productividad y uso eficiente de los recursos presentes. Otro objetivo es el de diseñar estrategias contextualizadas de conservación, difusión y puesta en valor del patrimonio cultural (tangible e intangible) y del medioambiente. Así, se quiere potenciar el desarrollo sostenible de las áreas rurales y analizar la eficacia de los sistemas agroecológicos y los problemas actuales de supervivencia en el contexto del cambio climático y en el marco de las normativas europeas. También se están llevando a cabo análisis de los servicios ecosistémicos para evaluar el papel que estos desempeñan en el mantenimiento de la diversidad (salvaje y cultivada) y poder trazar la trayectoria histórica de los agrosistemas para promover "Zonas Agrícolas de Alto Valor Natural". Además se desarrollarán propuestas que permitan mejorar la eficiencia en el uso de recursos y conservación de los paisajes. Para ello se promoverá el reconocimiento de las identidades de las poblaciones locales, en tanto que miembros activos poseedores de conocimientos que han de ser puestos en valor por las instituciones y difundidos con el fin de asegurar la supervivencia de los propios paisajes culturales. Finalmente, el proyecto MEMOLA propone desarrollar nuevas metodologías para el estudio de los paisajes culturales, basadas en el diseño de protocolos de trabaj o capaces de aprovechar los conocimientos tecnológicos y de herramientas de análisis disponibles en los grupos de investigación participantes. Así, se llevarán a cabo talleres, cursos y seminarios que potencien espacios en donde los diferentes equipos puedan compartir y aprender conjuntamente fortaleciendo de esta manera el trabajo interdisciplinar. La aplicación de una perspectiva multidisciplinar, que engloba tanto a especialistas en el estudio del patrimonio cultural, como a agrónomos, hidrólogos, botánicos, hidro-geólogos, geólogos y arquitectos, potenciará el desarrollo de nuevas metodologías de estudio del paisaje cultural, así como la promoción de nuevos perfiles laborales.

\section{IDENTIFICACIÓN DEL PROYECTO}

El proyecto MEMOLA/ $n .0613265$ está financiado por la Comisión Europea dentro del 7. Programa Marco (o FP7) y su duración es de cuatro años (2014-2018).
Another objective is to draw context-tailored strategies of preservation, diffusion and valorisation of the cultural heritage (both tangible and intangible) and of the environment. Stimulate sustainable development in rural areas and analyze the efficiency of these systems and the current problems of survival within the context of global climate change and the framework of European policies. This objective includes the analysis of ecosystem services to examine their role in maintaining biodiversity (wild and cultivated), and trace an historical trajectory of agro ecosystems leading to the creation of a "High Nature Value farmland". In addition, proposals will be developed for improving resources-use efficiency and conservation of cultural landscapes. The recognition and promotion of the local identity of rural communities within the study areas is an important piece in the research, as active members possessing the knowledge that must be preserved as a vehicle to ensure the survival of their own landscapes.

Finally, the MEMOLA project proposes to develop new methodologies for the study of cultural landscapes, through the creation of scalable working protocols, able to take advantage of the solid background of technologies and analysis methods available to the research group. For this, the project includes the organization of periodic workshops, courses and seminars among project members in order to share the different working techniques and specific methodologies of every area included in the study, thus contributing to the training of the research staff of each of the participant partners. Applying a multidisciplinary perspective widens the range of specialists involved in cultural heritage study to agronomist, hydrologists, botanists, hydrogeologists, geologists, architects, historians and archaeologists. Promoting skills-hybridization in research work (both humanist and scientific aspects), prompting new forms of job creation.

\section{Project identity}

The MEMOLA project/ n- 613265 has received funding from the European Union's Seventh Framework Programme (20142018).

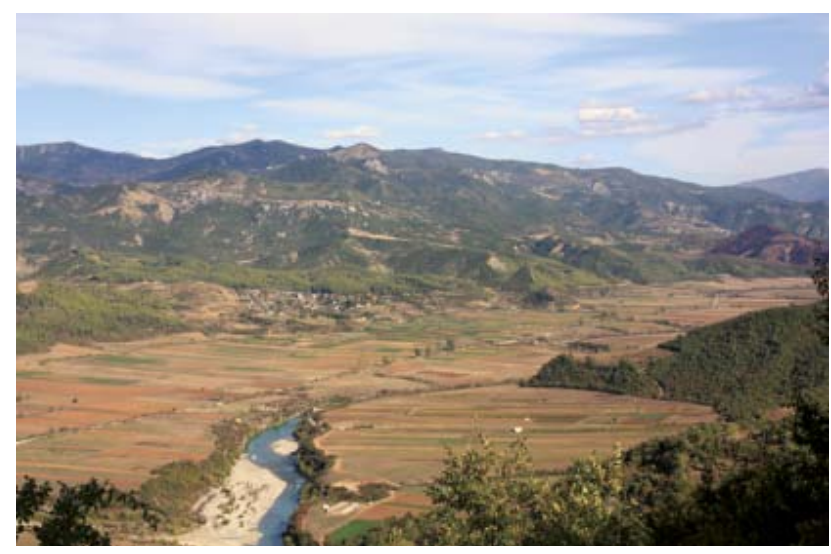

Vjosa Valley. 